Article

\title{
Seismic Response of Steel Moment Frames (SMFs) Considering Simultaneous Excitations of Vertical and Horizontal Components, Including Fling-Step Ground Motions
}

\author{
Shahrokh Shahbazi ${ }^{1}$, Armin Karami ${ }^{2} \mathbb{D}$, Jong Wan $\mathrm{Hu}^{3,4, * \mathbb{C}}$ and Iman Mansouri ${ }^{5}$ \\ 1 TAAT Investment Group, Tehran 18717-13553, Iran; shahrokh.shahbazi25@yahoo.com \\ 2 Department of Civil, Environmental and Land Management Engineering, Politecnico di Milano, \\ Milan 20133, Italy; armin.karami@mail.polimi.it \\ 3 Department of Civil and Environmental Engineering, Incheon National University, Incheon 22012, Korea \\ 4 Incheon Disaster Prevention Research Center, Incheon National University, Incheon 22012, Korea \\ 5 Department of Civil Engineering, Birjand University of Technology, Birjand 97175-569, Iran; \\ mansouri@birjandut.ac.ir \\ * Correspondence: jongp24@incheon.ac.kr; Tel.: +82-32-835-8463
}

Received: 16 March 2019; Accepted: 14 May 2019; Published: 20 May 2019

\begin{abstract}
Near-field (NF) earthquakes have drawn considerable attention from earthquake and structural engineers. In the field of earthquake engineering, numerous studies have identified the devastating nature of such earthquakes, and examined the characteristics related to the response of engineering structures to these types of earthquakes. Herein, special steel moment frames (SMFs) of three-, five-, and eight-story buildings have been examined via a nonlinear time history analysis in OpenSees software. The behavioral seismic differences of these frames have been evaluated in two states: (1) under the simultaneous excitation of the horizontal and vertical constituents of near-field earthquakes that have Fling-steps in their records; and (2) under simultaneous excitation of the horizontal and vertical constituents of far-field (FF) earthquakes. In addition, during modeling, the effects of panel zones have been considered. Considering that the simultaneous effects of the horizontal and vertical constituents of near-field earthquakes were subjected to a fling-step resulting in an increased inter-story drift ratio, the horizontal displacement of stories, an axial force of columns, created the moment in columns, base shearing of the structure, and velocity and acceleration of the stories.
\end{abstract}

Keywords: near-field earthquake; fling-step; far-field; simultaneous excitation; special moment frame (SMF)

\section{Introduction}

According to the elastic rebound theory, the sudden release of gradually accumulated stress and displacement in the earth's crust leads to the formation of a large permanent ground displacement over a few seconds and creates a fling-step [1] (Figure 1). The result would be a long-period pulse which is different from the better-known directivity pulse produced by the constructive interference of propagating seismic waves. Ventura et al. [2], and also Grimaz and Malisan [3], investigated the influences of fling-step on buildings through a parametric study; their study proves that the motion with the fling effect creates a much larger response than those without the fling effect (and thus potentially greater damage). Moreover, several studies have shown a considerable difference between the seismic demands of near- and far-field records. This is due to the high frequency content of near-field records and pulse-like behavior of these types of ground motions [4-8]. 




Figure 1. Ground motion depicting fling-step (i.e., static offset) from the YPT-N/S station in the 1999 Kocaeli, Turkey earthquake. $\mathrm{D}_{\mathrm{p}}$ : Displacement amplitude; $\mathrm{T}_{\mathrm{p}}$ : Period or duration; $\mathrm{T}_{1}$ : arrival time.

The main purpose of this paper is to develop a study of reference [8]. Kalkan and Kunnath [8] considered only the horizontal component of ground motion, while in this paper the simultaneous excitations of the horizontal and vertical constituents are considered. Besides, the panel zones are modeled in this paper, which were ignored in reference [8]. Among the seismic demands, only inter-story drift has been selected in the study of Kalkan and Kunnath, however in the present paper, in addition to inter-story drift, story displacement, columns' axial force, columns' moment, story shear, velocity and acceleration of story through an extensive post-processing are investigated.

Numerous studies have sought to clarify the response of buildings to diverse kinds of abbreviated pulses and create a design method for pulse-type records. For instance, references [9-11] evaluated the response of buildings and predicted the near-field response spectrum. References [12-17] examined the effects of pulse-like motions on building response. Moreover, the impacts on strength reduction factors were assessed in references [9,15,18,19]. Recently, Shahbazi et al. [14] studied the effects of soil classification on the seismic behavior of steel moment frames (SMFs), considering soil structure interactions and near-field ground motions.

An exclusive sine wave model for fling-step pulse waveforms was recently introduced by Burks and Baker [20]. However, a single sine wave cannot fully describe fling-step pulses, as they may consist of more than one frequency. Burks and Baker [20] presented a number of equations to predict the parameters of their model without the need for producing fling-step pulses.

Since these techniques take a lot of time, Farid Ghahari et al. [21] extracted the pulse component of a ground motion by adopting the moving average method. Soil structure interactions (SSIs) can also affect the response of buildings. The seismic evaluation of SMFs subjected to near-field ground motions with a forward directivity, including SSI impacts, were investigated by Shahbazi et al. [22], and the effect of fling-steps were ignored.

Moment frame systems are simply defined as assemblages of rigidly connected columns and beams [23-26], with its lateral strength mainly being achieved by the creation of bending moments and shear forces in the members and joints [27-30]. Owing to their pulse-like properties, near-field earthquakes result in a fast transmission of energy from the ground to the structure. Therefore, the elements in charge of increasing structural ductility fail to optimally perform. Thus, this study selected special steel moment frames, which have high ductility expectations. Moreover, in order to consider more realistic conditions in the modeling process, not only were the horizontal and vertical effects of near- and far-fault records simultaneously applied to the frames (which is the case in real earthquakes), but the effects of panel zone modeling were also incorporated. 


\section{The Effects and Characteristics of Near-Field Earthquakes}

Past studies show that near-field earthquakes have the critical energy of pulses. However, while these earthquakes may have a smaller magnitude than Richter, they have a high potential for damage. In general, near-field earthquakes have specific characteristics, which are briefly mentioned as follows:

(1) The velocity and acceleration history of these earthquakes have long-period pulses.

(2) The ratio of maximum velocity to the maximum acceleration of ground is significant in these earthquakes.

(3) Sometimes near-field quakes lead to major permanent transformations of the earth [31].

These characteristics arise from the many phenomena that occur near the seismic zone, which will be discussed later.

\section{Fling-Step Effect}

One of the recorded characteristics of the near-field records in last two decades, such as the 1999 earthquakes in Turkey and Taiwan, is the fling-step. This property occurred in the range of a few seconds of slip in the direction of the fault slip and is independent of the dynamic displacement originating from the directivity pulse of the ground's rupture. Accordingly, this phenomenon will affect components that are in the line of strike (parallel to the slip fault in strike-slip earthquakes, and in the direction of the slope in the dip-slip earthquakes).

For dip-slip earthquakes, fling-step and directivity effects occur in one direction and fling-step ground simultaneously occurs with maximum dynamic displacement, which must be considered as loads perpendicular to each other. The impact of the loads at one time is associated with a high potential for damage [32]. Briefly, fling-step ground is associated with a long-range velocity pulse and a uniform step in the time history of displacement. For instance, the Yarimka station experienced an approximately 2-meter permanent displacement during the Kjaili earthquake [33] (see Figure 2).

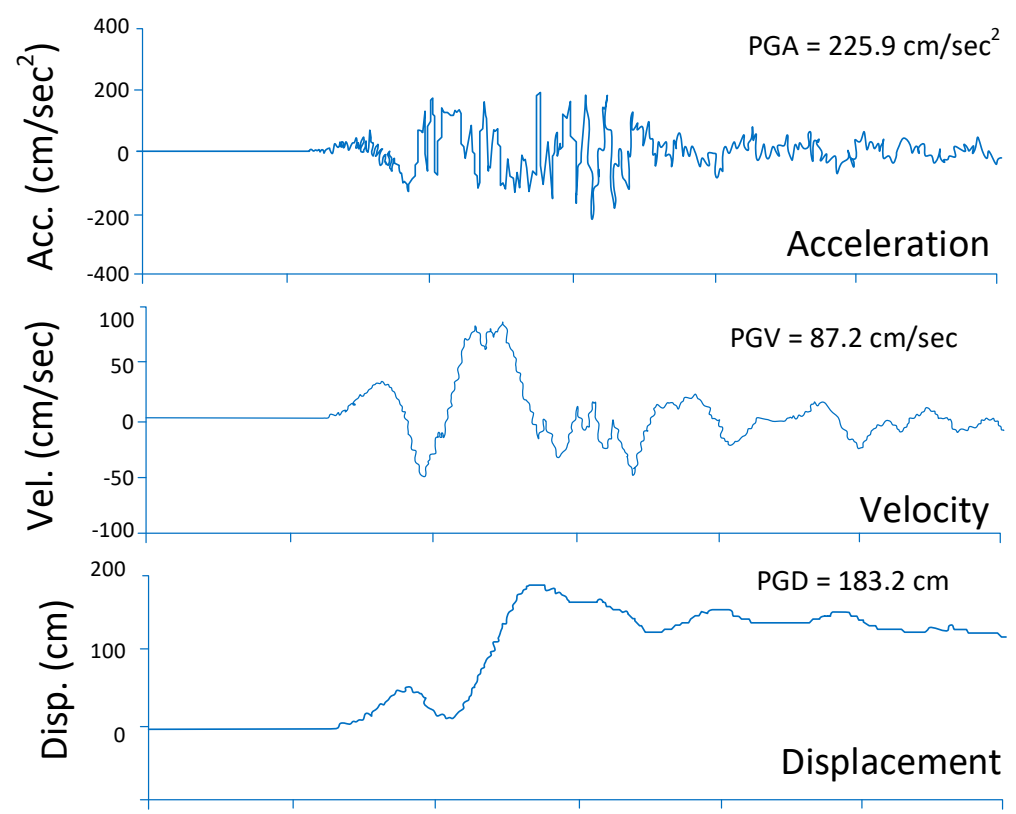

Figure 2. NS direction Yarimca station recordings during the Kocaeli earthquake [33].

The below figure is schematic of a strike-slip fault, the pulse is caused by the forward orientation and subsequent deformation which occurs in the perpendicular parameter and parallel to the major parameter of the fault, respectively. However, these two impacts are considered in the perpendicular parameters to the fault for dip-slip faults (see Figure 3), and time intervals where these factors are 
demonstrated with each other and separately are represented in Figure 4. Figure 3 displays the trend of pulse movement along with remnant displacement for strike-slip and dip-slip faults. The time interval plots caused by strike and reverse faults can be observed in Figure 4.

\section{STRIKE SLIP}

(Map View)

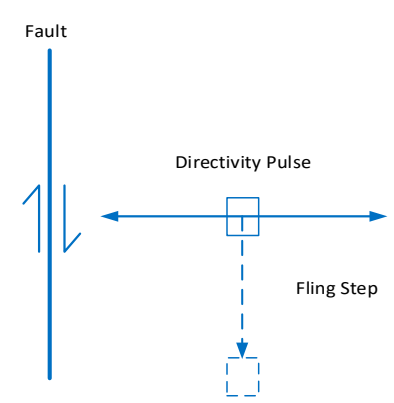

\section{DIP SLIP}

(Cross Section)

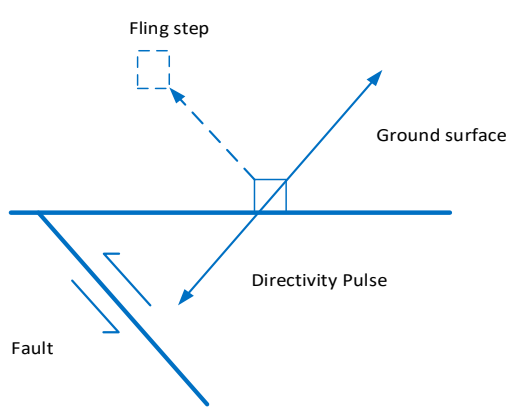

Figure 3. Conceptual plot representing the trends of the fling-step and directivity pulse for strike-slip and dip-slip faulting [32].

\section{Strike Normal \\ Component}

Strike-slip

Earthquake

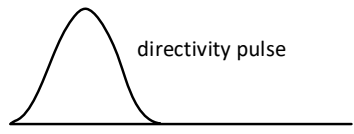

\section{Strike Parallel}

Component



fling step

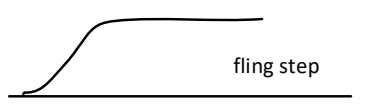

Dip-slip

Earthquake


Figure 4. Conceptual plot showing the time intervals of strike-slip and dip-slip faulting in which the fling-step and directivity pulse are displayed together and discretely [32].

\section{Numerical Models}

\subsection{Selected Numerical Models}

In the current research, steel moment skeletons of 3-, 5- and 8-floor with a particular ductility were applied for investigating the seismic behavior of three models founded on soil type $2\left(375 \mathrm{~m} / \mathrm{s} \leq \mathrm{V}_{\mathrm{s}}\right.$ (shear-wave velocity) $\leq 750 \mathrm{~m} / \mathrm{s}$ ). Seismic design of these three models was conducted using ETABS software and Iranian national construction codes [34]. The height of stories is $3.2 \mathrm{~m}$ and each of them was founded with three linear and lateral spans by the same width of $5 \mathrm{~m}$ [35]. In addition, corresponding columns and beams were chosen on both sides with stories undergoing similar efficiencies. Based on European standard cross sections, various kind of profiles were assumed for beams and columns, 
yielding cross sections which were employed in this research for beams and box-shapes were suggested for columns. As a result, the schematic model of the reference skeletons is illustrated in Figure 5. The profiles of the beams and columns for three-, five- and eight-story skeletons are presented in Table 1 . Furthermore, leaning columns were applied to modeling second order impacts (Figure 5).

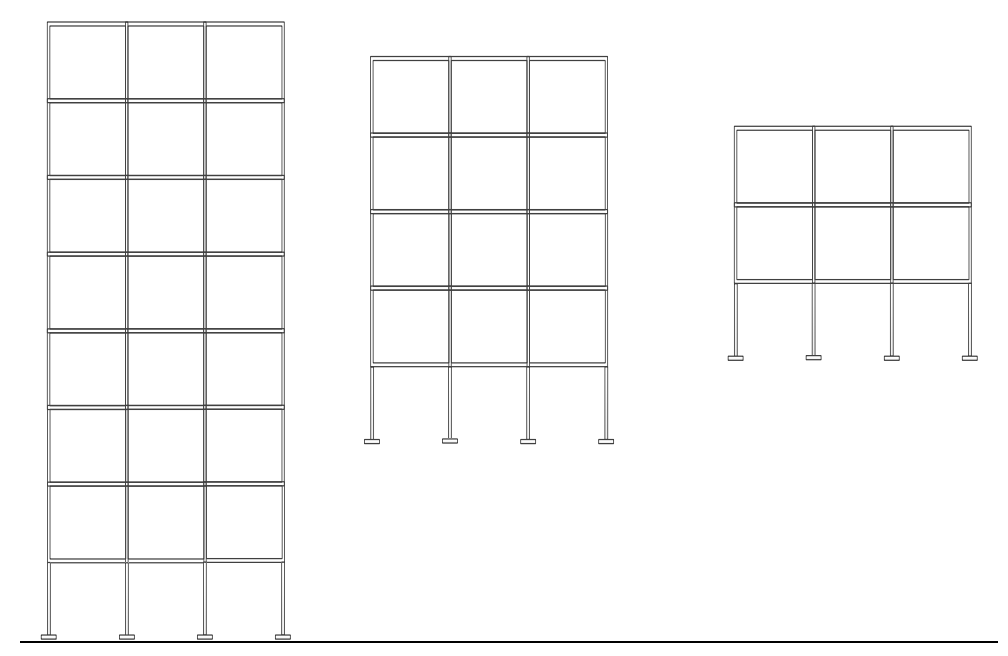

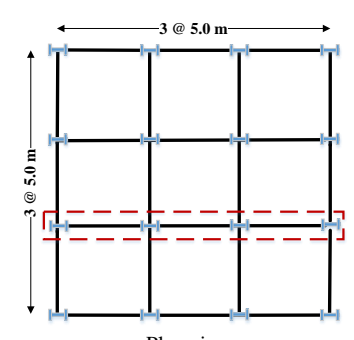

Plan view

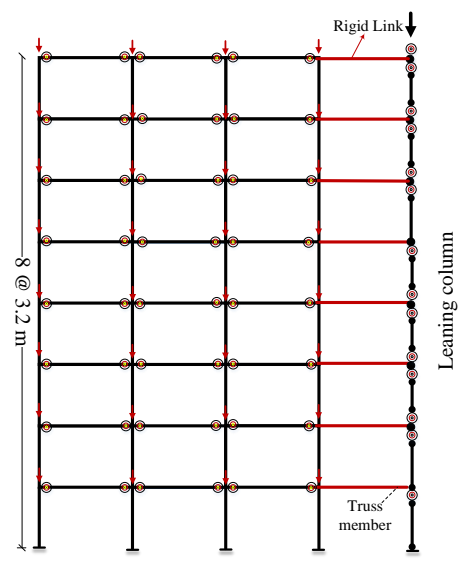

$x-5.0 \mathrm{~m}-x-5.0 \mathrm{~m}-x-5.0 \mathrm{~m}-$

Figure 5. Topology and grouping details of stories [26].

Table 1. The section of structures.

\begin{tabular}{|c|c|c|c|c|c|c|c|}
\hline & No. & Column & Beam & & No. & Column & Beam \\
\hline \multirow{5}{*}{ 3-story } & 1 & Box $200 \times 200 \times 20$ & IPE 300 & \multirow{12}{*}{ 8-story } & 1 & Box $280 \times 280 \times 20$ & IPE 400 \\
\hline & 2 & Box $200 \times 200 \times 20$ & IPE 300 & & 2 & Box $280 \times 280 \times 20$ & IPE 400 \\
\hline & 3 & Box $200 \times 200 \times 20$ & IPE 270 & & 3 & Box $240 \times 240 \times 20$ & IPE 360 \\
\hline & 4 & Box $280 \times 280 \times 20$ & IPE 400 & & 4 & Box $180 \times 180 \times 20$ & IPE 330 \\
\hline & 5 & Box $280 \times 280 \times 20$ & IPE 300 & & 5 & Box $400 \times 400 \times 20$ & IPE 400 \\
\hline \multirow{7}{*}{ 5-story } & 6 & Box $280 \times 280 \times 20$ & IPE 270 & & 6 & Box $340 \times 340 \times 20$ & IPE 450 \\
\hline & 1 & Box $240 \times 240 \times 20$ & IPE 330 & & 7 & Box $300 \times 300 \times 20$ & IPE 400 \\
\hline & 2 & Box $240 \times 240 \times 20$ & IPE 360 & & 8 & Box $240 \times 240 \times 20$ & IPE 360 \\
\hline & 3 & Box $180 \times 180 \times 20$ & IPE 240 & & & & \\
\hline & 4 & Box $300 \times 300 \times 20$ & IPE 330 & & & & \\
\hline & 5 & Box $300 \times 300 \times 20$ & IPE 360 & & & & \\
\hline & 6 & Box $240 \times 240 \times 20$ & IPE 240 & & & & \\
\hline
\end{tabular}


The following symbol is applied for the columns place in the analysis result section (in Section 4 of paper):

$\mathrm{Cij}^{*}$ is the code for position of results in the columns;

$\mathrm{i}=$ story number;

$\mathrm{j}=$ number of columns located in the left-hand of buildings.

There are different assumptions being considered in this research. Dead (fixed) load on a building is due to the weight of constant elements including beams, floor segments, columns and walls. The fixed load is used as a monotonic distributed load parallel to each beam, column, or wall and as a surface load for the deck/segment. The magnitude of the beam and column loads equals the surface area times the material weight density. The magnitude of the wall load equals wall's thickness times the wall height times the material density. The live load is calculated based on the standard loading code. The live and live loads of $20 \mathrm{kN} / \mathrm{m}^{2}$ and $65 \mathrm{kN} / \mathrm{m}^{2}$, respectively [36], were applied to all stories. But different loads were applied for roofs, at $54 \mathrm{kN} / \mathrm{m}^{2}$ and $15 \mathrm{kN} / \mathrm{m}^{2}$, respectively [26,37]. All models were fulfilled based on the rigid bed which was used for all stories. Elastic elements were considered for all beam and columns in OpenSees software which has been employed for modeling these structures. Bilin non-multi linear materials were used in order to describe the behavioral properties of elements [26]. The Krawinkler panel zone model was selected in this research (see Figure 6). The parameters of the Bilin material were obtained based on the study by Lignos and Krawinkler [38].

Panel zone distortion occurs mainly in shear because of contrary moments in the columns and beams. Panel zone modeling is explicitly performed through the method described by [39]. In this approach, modelling of the panel zone is performed in a rectangular pattern with eight very stiff elastic beam-column components. Shear deformation in the panel zone is shown by one rotational source (Figure 6).

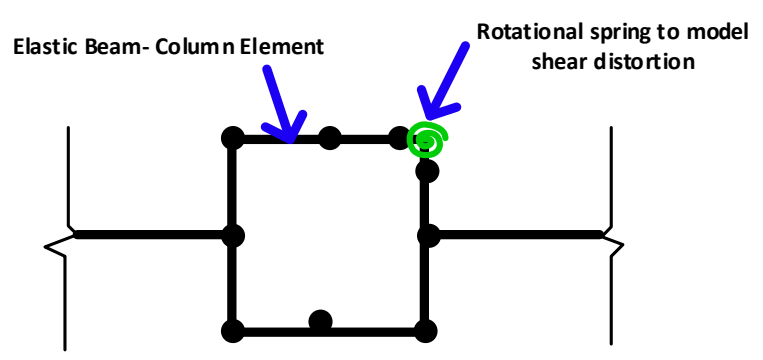

Figure 6. Conceptual display of an ordinary panel zone [40].

The Bilin material is defined as the corrected deterioration model of Ibarra-Medina-Krawinkler with a bilinear disturbed response. Figure 7 presents the components of the Bilin material. Lignos and Krawinkler presented the relationships between the variables [38]. The 3-, 5- and 8-story buildings have fundamental periods equal to $0.48,0.91$, and $0.78 \mathrm{~s}$, respectively. 


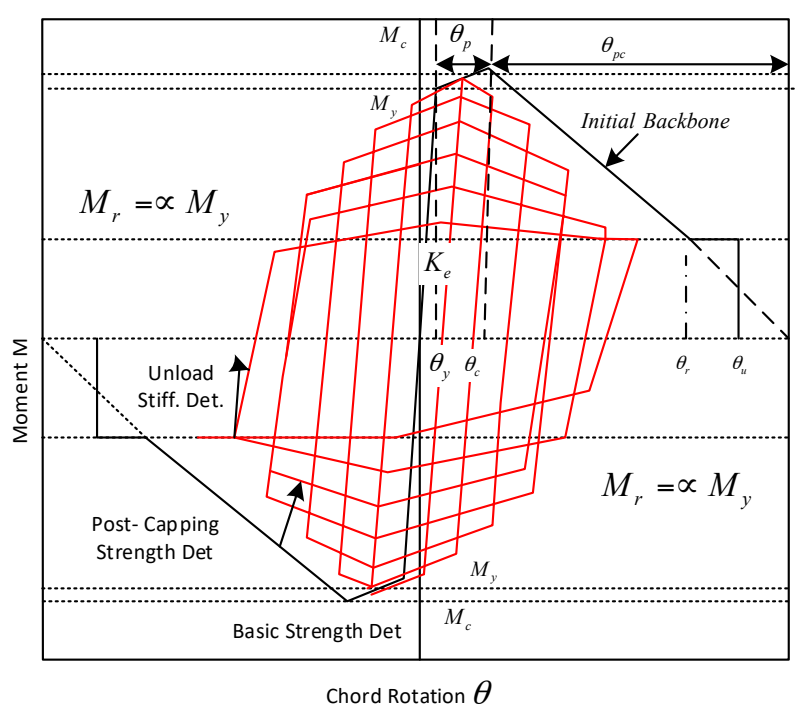

Figure 7. The corrected deterioration model of Ibarra-Medina-Krawinkler [38].

For simulating the nonlinear behavior of the investigated structures, their modeling was performed by using elastic beam-column components in association with rotational sources. According to the corrected IMK (Ibarra-Medina-Krawinkler) deterioration approach, the sources are supposed to represent a bilinear hysteretic reaction. Rotational springs are employed to represent the nonlinear behavior of moment frames using the concentrated plasticity concept.

A rotational spring, located at the center of the reduced beam sections (RBS) and connected to the panel zone through an elastic beam-column member, is used to model the plastic hinge. Each frame member is modeled as an elastic element with two rotational springs at either end to connect it to other elastic elements. Therefore, in order to simulate the stiffness of the actual frame member, the stiffness of different components of the structure should be adjusted [41].

\subsection{Records Selection}

Choosing the appropriate record is one of the most important parts of time history analysis. In this research, 12 earthquake records have been selected for nonlinear time history analysis, meanwhile, near-field earthquakes have the effects of fling-step earthquakes. The characteristics of these seismographs have been presented in Table 2.

\section{Evaluating the Seismic Response of Structures}

The 5\% damped response spectrum should be produced and combined for each couple by applying the square root of the sum of the square (SRSS) approach, so that a specific spectrum is built for each couple. Ground movements should be measured such that the mean value of their SRSS spectra does not decrease less than 1.4 times the standard design spectra during $0.2 T-1.5 T$ seconds, where $T$ indicates [34].

The present research analyzed 36 nonlinear time histories according to 12 chosen ground motions. The maximum inter-story drift ratio was used as the first criterion for assessing the seismic demand on the structures. Figure 8 shows the maximum drift ratio stemming from the nonlinear time history analysis under the simultaneous effects of the horizontal as well as vertical components of ground motions for buildings with a special moment framework. 
Table 2. Earthquake records selection [8].

\begin{tabular}{|c|c|c|c|c|c|c|c|c|c|c|c|c|}
\hline No & \#Earthquakes & Year & Event & Mech $^{\text {a }}$ & Station & Comp & $\begin{array}{l}\text { Site } \\
\text { Class }\end{array}$ & Mw & $\begin{array}{l}\text { PGA } \\
\text { (g) }\end{array}$ & $\begin{array}{l}\text { PGV } \\
(\mathrm{cm} / \mathrm{s})\end{array}$ & PGD (cm) & $\begin{array}{l}\text { Fling } \\
\text { Disp. } \\
\text { (cm) }\end{array}$ \\
\hline \multicolumn{13}{|c|}{ (a) Far-Field Recordings Vertical } \\
\hline 1 & $\# \mathrm{EQF}_{\mathrm{V}} 1$ & 1992 & Big Bear & SS & $\begin{array}{c}\text { Desert } \\
\text { Hot Spr. }\end{array}$ & 90 & Soil & 6.4 & 0.11 & 10 & 1.21 & - \\
\hline 2 & $\# \mathrm{EQF}_{\mathrm{V}} 2$ & 1952 & $\begin{array}{l}\text { Kern } \\
\text { County }\end{array}$ & $\mathrm{TH} / \mathrm{REV}$ & Taft & 111 & Soil & 7.5 & 0.11 & 7 & 5.76 & - \\
\hline 3 & $\# \mathrm{EQF}_{\mathrm{V}} 3$ & 1989 & $\begin{array}{l}\text { Loma } \\
\text { Prieta }\end{array}$ & OB & $\begin{array}{c}\text { Cliff } \\
\text { House }\end{array}$ & 90 & Stiff Soil & 7.0 & 0.06 & 0.07 & 1.43 & - \\
\hline \multicolumn{13}{|c|}{ (b) Far-Field Recordings Horizontal } \\
\hline 1 & $\# \mathrm{EQF}_{\mathrm{H}} 1$ & 1992 & Big Bear & SS & $\begin{array}{c}\text { Desert } \\
\text { Hot Spr. }\end{array}$ & 90 & Soil & 6.4 & 0.23 & 19.14 & 4.53 & - \\
\hline 2 & $\# \mathrm{EQF}_{\mathrm{H}} 2$ & 1952 & $\begin{array}{c}\text { Kern } \\
\text { County }\end{array}$ & $\mathrm{TH} / \mathrm{REV}$ & Taft & 111 & Soil & 7.5 & 0.18 & 17.50 & 8.79 & - \\
\hline 3 & $\# \mathrm{EQF}_{\mathrm{H}} 3$ & 1989 & $\begin{array}{l}\text { Loma } \\
\text { Prieta }\end{array}$ & OB & $\begin{array}{l}\text { Cliff } \\
\text { House }\end{array}$ & 90 & Stiff Soil & 7.0 & 0.11 & 19.79 & 5.02 & - \\
\hline \multicolumn{13}{|c|}{ (c) Near-Field Recordings (Fling-step) Horizontal } \\
\hline 1 & $\# \mathrm{EQN}_{\mathrm{H}} 1$ & 1999 & Chi-Chi & $\mathrm{TH}$ & TCU084 & NS & Soil & 7.6 & 0.42 & 42.63 & 64.91 & 59.43 \\
\hline 2 & $\# \mathrm{EQN}_{\mathrm{H}} 2$ & 1999 & Chi-Chi & $\mathrm{TH}$ & TCU052 & NS & Soil & 7.6 & 0.44 & 216 & 709.09 & 697.12 \\
\hline 3 & $\# \mathrm{EQN}_{\mathrm{H}} 3$ & 1999 & Chi-Chi & $\mathrm{TH}$ & TCU0129 & NS & Soil & 7.6 & 0.61 & 54.56 & 82.70 & 67.54 \\
\hline \multicolumn{13}{|c|}{ (d) Near-Field Recordings (Fling-step) Vertical } \\
\hline 1 & $\# \mathrm{EQN}_{\mathrm{V}} 1$ & 1999 & Chi-Chi & $\mathrm{TH}$ & TCU084 & NS & Soil & 7.6 & 0.32 & 25 & 13.24 & - \\
\hline 2 & $\# \mathrm{EQN}_{\mathrm{V}} 2$ & 1999 & Chi-Chi & $\mathrm{TH}$ & TCU052 & NS & Soil & 7.6 & 0.34 & 38.8 & 24.39 & - \\
\hline 3 & $\# \mathrm{EQN}_{\mathrm{V}} 3$ & 1999 & Chi-Chi & $\mathrm{TH}$ & TCU0129 & NS & Soil & 7.6 & 0.19 & 24.4 & 154 & - \\
\hline \multicolumn{13}{|c|}{ (e) Near-Field Recordings (Non Fling-step) } \\
\hline 1 & \#EQN1 & 1989 & $\begin{array}{l}\text { Loma } \\
\text { Prieta }\end{array}$ & OB & LGPC & 00 & Stiff Soil & 7.0 & 0.56 & 94.81 & 41.13 & - \\
\hline 2 & \#EQN2 & 1994 & Northridge & $\mathrm{TH}$ & $\begin{array}{l}\text { Olive } \\
\text { view }\end{array}$ & 360 & Soil & 6.7 & 0.84 & 130.37 & 31.72 & - \\
\hline 3 & \#EQN3 & 1992 & $\begin{array}{c}\text { Cape } \\
\text { Mendocino }\end{array}$ & $\mathrm{TH}$ & Petrolia & 90 & Stiff Soil & 7.1 & 0.66 & 90.16 & 28.89 & - \\
\hline
\end{tabular}

${ }^{\text {a }}$ Faulting Mechanism = TH: Thrust; REV: Reverse; SS: Strike-slip; OB: Oblique. 

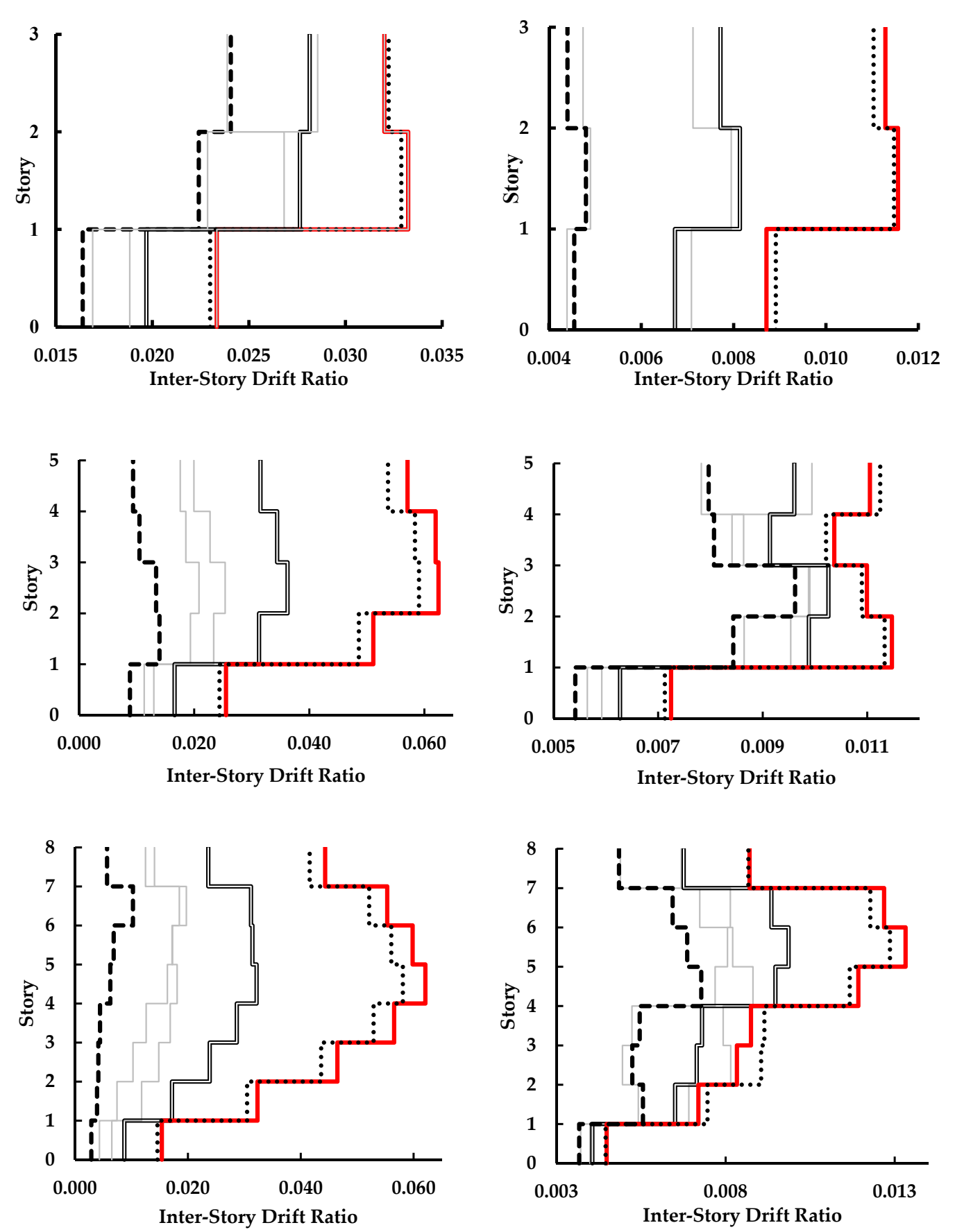

\#Earthquakes

Max $\longrightarrow$ Mean

Mean+Std ---- Mean-Std

Figure 8. The maximum inter-story drift ratio of stories in studied frames under the simultaneous effects of the vertical and horizontal constituents of far- and near-field ground motions with fling-step records.

The graphs suggest that, in a three-story building, the maximum inter-story drift ratio was 0.03 under the simultaneous effects of the horizontal and vertical constituents of near-field earthquakes with fling-step and 0.01 for far-field earthquakes. These maximum ratios are associated with Big Bear $\left(\#\left(\# E_{(\mathrm{V}+\mathrm{H})} 1\right)\right.$ and Chi-Chi-52 records $\left(\# \mathrm{EQN}_{(\mathrm{V}+\mathrm{H})} 2\right)$, and emerged on the second floor of the structure in both earthquakes. In addition, the maximum inter-story drift ratio was three times larger in the near-field earthquake compared to that in the far-field earthquake. 
This maximum ratio was 0.01 subjected to the influence of far-field records and 0.06 subjected to the effect of near-field records in a five-story building, which were respectively associated with Chi-Chi-52 \#EQN $(\mathrm{V}+\mathrm{H}) 2$ ) and Kern County $\left(\# \mathrm{EQF}_{(\mathrm{V}+\mathrm{H})} 2\right)$. The inter-story drift ratio was maximized on the second floor of the structure subjected to the influence of Chi-Chi-52 $(\# \mathrm{EQN}(\mathrm{V}+\mathrm{H}) 2)$ and on the third floor in Kern County $\left(\# \mathrm{EQF}_{(\mathrm{V}+\mathrm{H})} 2\right)$. This maximum ratio was six times larger in the near-field earthquake compared to in the far-field earthquake. Although this trend is similar in both buildings, the inter-story drift ratio was maximized on the sixth floor of the five-story building in the near-field earthquake of Big Bear $(\# \mathrm{EQF}(\mathrm{V}+\mathrm{H}) 1)$ and on the fifth floor of the eight-story building in Chi-Chi-52 $\left(\# \mathrm{EQN}_{(\mathrm{V}+\mathrm{H})}\right.$ )). Table 3 compares the average maximum inter-story drift ratio in all three structures for far-field and near-field earthquakes. In this table, "Near/Far" denotes the ratio of near- and far-field.

Table 3. Comparison of the average of seismic response parameters of studied frames under to the simultaneous effects of the horizontal and vertical constituents of far- and near-field earthquakes with fling-step records.

\begin{tabular}{|c|c|c|c|c|c|}
\hline Story & Field & $\begin{array}{c}\text { Inter-Story Drift Ratio } \\
(\text { Max) } \\
\text { Ave }\end{array}$ & Near/Far & Displacement $_{\text {Ave }}(\mathrm{m})$ & Near/Far \\
\hline \multirow{2}{*}{3} & Near & 0.03 & \multirow{2}{*}{3} & 0.23 & \multirow{2}{*}{3.29} \\
\hline & Far & 0.01 & & 0.07 & \\
\hline \multirow[b]{2}{*}{5} & Near & 0.04 & \multirow[b]{2}{*}{4} & 0.47 & \multirow[b]{2}{*}{3.36} \\
\hline & Far & 0.01 & & 0.14 & \\
\hline \multirow{2}{*}{8} & Near & 0.03 & \multirow{2}{*}{3} & 0.58 & \multirow{2}{*}{3.41} \\
\hline & Far & 0.01 & & 0.17 & \\
\hline \multirow{3}{*}{3} & & Axial Force $_{\text {Ave }}(\mathbf{k N})$ & \multirow{3}{*}{2.16} & Moment $_{\text {Ave }}(\mathrm{kN} \cdot \mathrm{m})$ & \multirow{3}{*}{2.64} \\
\hline & Near & 500.8 & & 552.7 & \\
\hline & Far & 232.1 & & 209.5 & \\
\hline \multirow{2}{*}{5} & Near & 1173.5 & \multirow{2}{*}{1.75} & 1078.2 & \multirow[b]{2}{*}{2.35} \\
\hline & Far & 672.6 & & 458.3 & \\
\hline \multirow[b]{2}{*}{8} & Near & 2250.9 & \multirow[b]{2}{*}{1.55} & 1376.1 & \multirow[b]{2}{*}{1.9} \\
\hline & Far & 1448 & & 723.1 & \\
\hline \multirow{3}{*}{3} & & $\operatorname{Acceleration}_{\text {Ave }}\left(\mathrm{m} / \mathrm{s}^{2}\right)$ & \multirow{3}{*}{2.09} & Velocity Ave $_{\text {(m/s) }}$ & \multirow{3}{*}{2.12} \\
\hline & Near & 17.76 & & 1.42 & \\
\hline & Far & 8.48 & & 0.67 & \\
\hline \multirow{2}{*}{5} & Near & 18.57 & \multirow{2}{*}{1.74} & 2.06 & \multirow{2}{*}{1.93} \\
\hline & Far & 10.67 & & 1.07 & \\
\hline \multirow{2}{*}{8} & Near & 20.48 & \multirow{2}{*}{2.02} & 2.39 & \multirow{2}{*}{2.06} \\
\hline & Far & 10.15 & & 1.16 & \\
\hline
\end{tabular}

In the three-story building, the maximum horizontal displacement of the roof under the simultaneous influence of the horizontal and vertical constituents was $0.28 \mathrm{~m}$ for the near-field earthquake and $0.10 \mathrm{~m}$ for the far-field earthquake. This displacement was caused by the Big $\operatorname{Bear}\left(\# \mathrm{EQF}_{(\mathrm{V}+\mathrm{H})} 1\right)$ and the Chi-Chi-52 $\left(\# \mathrm{EQN}_{(\mathrm{V}+\mathrm{H})} 2\right)$ records. The displacement imposed on the structure by the near-field earthquake was 2.8 times greater than that caused by the far-field earthquake.

According to the Kern County $\left(\# \mathrm{EQF}_{(\mathrm{V}+\mathrm{H})}\right)$ and Chi-Chi-52(\#EQN $\left.(\mathrm{V}+\mathrm{H}) 2\right)$ records, in the five-story building, the maximum horizontal displacement of the roof was $0.18 \mathrm{~m}$ under the simultaneous effects of the horizontal and vertical constituents of the near-field earthquake and $0.14 \mathrm{~m}$ for the far-field earthquake with the fling-step earthquake. The horizontal displacement of the roof in the five-story building subject to the near-fault ground motions was therefore 5.86 times greater than that of the far-field earthquake.

According to the Big Bear $(\# \mathrm{EQF}(\mathrm{V}+\mathrm{H}) 1)$ and Chi-Chi-52 $\left(\# \mathrm{EQN}_{(\mathrm{V}+\mathrm{H})} 2\right)$ records, the maximum horizontal displacement of the eight-story building was $1.15 \mathrm{~m}$ when subjected to the influence of both components of the near earthquake and $0.21 \mathrm{~m}$ when subjected to the influence of the far-fault ground motions. The horizontal displacement of the roof in the near-field earthquake was therefore 5.48 times higher than that of the far-field earthquake. Table 3 compares the average maximum horizontal displacement subjected to influences of far-field and near-field earthquakes. 
The maximum axial force developed in the $\mathrm{C} 12$ column on the first floor of the three-story building was $582.10 \mathrm{kN}$ when subjected to the influences of both the horizontal and vertical constituents of the near-fault record with fling-step and $289.50 \mathrm{kN}$ when subjected to the influences of the far-field earthquake (Table 1). The Big Bear $\left(\# \mathrm{EQF}_{(\mathrm{V}+\mathrm{H})} 1\right)$ and Chi-Chi-29 $\left(\# \mathrm{EQN}_{(\mathrm{V}+\mathrm{H})} 3\right)$ records respectively imposed these forces on the columns. The peak axial force created in the column subjected to the influence of both components of the near-field earthquake was therefore 2.01 times higher than that of the far-field earthquake.

According to the Big Bear $(\# \mathrm{EQF}(\mathrm{V}+\mathrm{H}) 1)$ and Chi-Chi-52 $\left(\# \mathrm{EQN}_{(\mathrm{V}+\mathrm{H})} 2\right)$ records, the peak axial force developed by the near-fault record in the $\mathrm{C} 13$ column of the first floor of the eight-story building was $3109.9 \mathrm{kN}$ and that by the far-field earthquake was $1598.50 \mathrm{kN}$. The maximum force developed by the near-field earthquake in the column was therefore 1.95 times higher than that developed by the far-field earthquake. Table 3 compares the average maximum axial force in the column subjected to the influence of far-field and near-field ground motions.

According to the Big Bear $\left(\# \mathrm{EQF}_{(\mathrm{V}+\mathrm{H})} 1\right)$ and Chi-Chi-52 $\left(\# \mathrm{EQN}_{(\mathrm{V}+\mathrm{H})} 2\right)$ records, the maximum moment developed in the $\mathrm{C} 11$ column of the first floor of the three-story building subjected to the simultaneous effects of the horizontal and vertical constituents of the near-fault records with a fling-step earthquake was $613.60 \mathrm{kN} \cdot \mathrm{m}$, and that of the far-field earthquake was $265.60 \mathrm{kN} \cdot \mathrm{m}$. The maximum moment developed by the near-field earthquake was therefore 2.31 times higher than that of the far-field earthquake.

According to the Kern County $\left(\# \mathrm{EQF}_{(\mathrm{V}+\mathrm{H})} 2\right)$ and Chi-Chi-52 $\left(\# \mathrm{EQN}_{(\mathrm{V}+\mathrm{H})} 2\right)$ records, the maximum moment developed in the $\mathrm{C} 13$ column subjected to the effects of the horizontal and vertical constituents of the near-field earthquake was $1578.00 \mathrm{kN} \cdot \mathrm{m}$ and that of the far-field earthquake was $522.50 \mathrm{kN} \cdot \mathrm{m}$. The moment created in the column by the near-field earthquake was therefore 3.02 times higher than that created by the far-field earthquake.

According to the Big Bear $\left(\# \mathrm{EQF}_{(\mathrm{V}+\mathrm{H})} 1\right)$ and Chi-Chi-52 (\#EQN $\left.(\mathrm{V}+\mathrm{H}) 2\right)$ records, the maximum moment developed in the $\mathrm{C} 13$ column of the first floor of the eight-story building by the near-field earthquake was $2316.90 \mathrm{kN} \cdot \mathrm{m}$ and that developed by the far-field earthquake was $796.80 \mathrm{kN} \cdot \mathrm{m}$. The maximum axial force developed by the near-field earthquake was therefore 2.91 times higher than that developed by the far-field earthquake. Table 3 compares the average maximum moment of the column subjected to the influence of far-field and near-field records.

According to the Big Bear $\left(\# \mathrm{EQF}_{(\mathrm{V}+\mathrm{H})} 1\right)$ and Chi-Chi-52 $(\# \mathrm{EQN}(\mathrm{V}+\mathrm{H}) 2)$ records, the maximum story shear developed in the three-story building subjected to the influences of the near-field and far-field earthquakes was $3940.80 \mathrm{kN}$ and $3519.30 \mathrm{kN}$, respectively. The maximum story shear developed in the three-story building by the near-field earthquake was therefore $12 \%$ higher than that developed by the far-field earthquake.

According to the Big Bear $\left(\# \mathrm{EQF}_{(\mathrm{V}+\mathrm{H})} 1\right.$ (and Chi-Chi-52 $\left(\# \mathrm{EQN}_{(\mathrm{V}+\mathrm{H})} 2\right)$ records, the maximum story shear developed in the five-story building was $11,727.70 \mathrm{kN}$ when subjected to the near-field earthquake and $9929.40 \mathrm{kN}$ when subjected to the far-field earthquake. The maximum story shear developed by the near-field earthquake was therefore 1.18 times higher than that developed by the far-field earthquake.

According to the Big Bear $(\# \mathrm{EQF}(\mathrm{V}+\mathrm{H}) 1)$ and Chi-Chi-29 $(\# \mathrm{EQF}(\mathrm{V}+\mathrm{H}) 3)$ records, the maximum story shear created in the eight-story building by the near-field earthquake was $42,066.80 \mathrm{kN}$, and by the far-field earthquake $27,993.00 \mathrm{kN}$. The maximum story shear created in the eight-story building subjected to the influence of the near-field earthquake was 1.5 times higher than that of the far-field earthquake. Table 4 compares the average maximum story shear subjected to the influence of far-field and near-field earthquakes. 
Table 4. Comparison of the mean story shear created in the stories of studied frames subjected to the simultaneous effects of the horizontal and vertical constituents of both far- and near-fault records with fling-step ground motions.

\begin{tabular}{|c|c|c|c|}
\hline & Field & Story Shear Ave $(k N)$ & Near/Far \\
\hline \multirow{2}{*}{3} & Near & 3856.2 & \multirow{2}{*}{1.37} \\
\hline & Far & 2816.4 & \\
\hline \multirow{2}{*}{5} & Near & $11,288.9$ & \multirow{2}{*}{1.47} \\
\hline & Far & 7704.8 & \\
\hline \multirow{2}{*}{8} & Near & $35,543.9$ & \multirow{2}{*}{1.68} \\
\hline & Far & $21,204.1$ & \\
\hline
\end{tabular}

According to research and the Big Bear $\left(\# \mathrm{EQF}_{(\mathrm{V}+\mathrm{H})} 1\right)$ and Chi-Chi-29 $\left(\# \mathrm{EQN}(\mathrm{V}+\mathrm{H}){ }^{3}\right)$ records, the maximum acceleration developed on the floors of the three-story building under the simultaneous effects of the horizontal and vertical constituents of the near-field earthquake was $28.38 \mathrm{~m} / \mathrm{s}^{2}$ and $10.81 \mathrm{~m} / \mathrm{s}^{2}$ for the far-field earthquake. The maximum acceleration created by the near-field earthquake was therefore 2.63 times higher than that created by the far-field earthquake.

In the five-story building, the maximum acceleration developed by the near-field earthquake of Big Bear $\left(\# E_{E F}(\mathrm{~V}+\mathrm{H}) 1\right)$ was $19.49 \mathrm{~m} / \mathrm{s}^{2}$ and that by the far-field earthquake of Chi-Chi-29 (\#EQN $(\mathrm{V}+\mathrm{H})$ 3) was $12.74 \mathrm{~m} / \mathrm{s}^{2}$. The maximum acceleration was developed on the fourth floor in the near-field earthquake and on the roof of the building in the far-field earthquake. The maximum acceleration developed by the near-field earthquake was therefore 1.53 higher than that developed by the far-field earthquake.

The maximum acceleration developed on the roof of the eight-story building by the near-field earthquake of Big Bear $\left(\# \mathrm{EQF}_{(\mathrm{V}+\mathrm{H})} 1\right)$ was $23.34 \mathrm{~m} / \mathrm{s}^{2}$, and that developed by the far-field earthquake of Chi-Chi-52 (\#EQN $(\mathrm{V}+\mathrm{H}) 2)$ was $12.02 \mathrm{~m} / \mathrm{s}^{2}$. The maximum acceleration developed by the near-field earthquake was therefore 1.94 times higher than that developed by the far-field earthquake. Table 3 compares the average maximum acceleration subjected to the influence of far-field and near-field earthquakes.

The maximum velocity developed on the floors of the three-story building was $1.57 \mathrm{~m} / \mathrm{s}$ under the simultaneous effects of the horizontal and vertical constituents of the near-field earthquake and $0.91 \mathrm{~m} / \mathrm{s}$ by the far-field earthquake, which were imposed on the roof of the structure by the records of Big Bear $\left(\# E_{E N}(\mathrm{~V}+\mathrm{H}) 1\right)$ and Chi-Chi-84 $\left(\# \mathrm{EQN}_{(\mathrm{V}+\mathrm{H})}\right)$ ). The maximum velocity caused by the near-field earthquake was therefore 1.73 times higher than that caused by the far-field earthquake.

The maximum velocity developed on the roof of the five-story building by the near-field earthquake of Kern County ( $\# \mathrm{EQF}(\mathrm{V}+\mathrm{H}) 2)$ was $2.50 \mathrm{~m} / \mathrm{s}$ and by the far-field earthquake of Chi-Chi-52 $(\# \mathrm{EQN}(\mathrm{V}+\mathrm{H}) 2)$ was $1.18 \mathrm{~m} / \mathrm{s}$. The maximum velocity caused by the near-field earthquake was therefore 2.12 times higher than that caused by the far-field earthquake.

The maximum velocity developed on the roof of the eight-story building by the near-field earthquake of Big Bear $(\# \mathrm{EQF}(\mathrm{V}+\mathrm{H}) 1)$ was $3.56 \mathrm{~m} / \mathrm{s}$ and that developed by the far-field earthquake of Chi-Chi-52 (\#EQN $(\mathrm{V}+\mathrm{H}) 2)$ was $1.40 \mathrm{~m} / \mathrm{s}$. The maximum velocity caused by the near-field earthquake was therefore 2.54 times higher than that caused by the far-field earthquake. Table 3 compares the average maximum horizontal displacement subjected to influence of far-field and near-field earthquakes.

Moreover, the fling-step versus near-field no fling-step motions is investigated. The results show that the average of maximum inter-story drift, story displacement, axial force of columns, end moment of columns, velocity and acceleration of the story under fling-step ground motions are less than those with near-field no fling-step motions (Table 5). However, Table 6 reveals that the story shear is higher in the case of fling-step records. 
Table 5. Comparison of the average of seismic response parameters of the studied frames under the simultaneous effects of the horizontal and vertical constituents of near-field earthquakes with fling-step and non-fling-step records.

\begin{tabular}{|c|c|c|c|c|c|}
\hline Story & Near Field & $\begin{array}{l}\text { Inter-Story Drift Ratio } \\
(\text { Max })_{\text {Ave }}\end{array}$ & $\begin{array}{l}\text { F-S/Non } \\
\text { F-S }\end{array}$ & Displacement $_{\text {Ave }}(\mathrm{m})$ & $\begin{array}{c}\text { F-S/Non } \\
\text { F-S }\end{array}$ \\
\hline \multirow{3}{*}{3} & $\begin{array}{c}\text { F-S } \\
\text { (fling-step) }\end{array}$ & 0.03 & \multirow{3}{*}{0.75} & 0.23 & \multirow{3}{*}{0.68} \\
\hline & Non-F-S & & & & \\
\hline & (Non-fling-step) & 0.04 & & 0.34 & \\
\hline \multirow{2}{*}{5} & F-S & 0.04 & \multirow{2}{*}{0.8} & 0.47 & \multirow{2}{*}{0.89} \\
\hline & Non-F-S & 0.05 & & 0.53 & \\
\hline \multirow[b]{2}{*}{8} & F-S & 0.03 & \multirow{2}{*}{0.75} & 0.58 & \multirow[b]{2}{*}{0.92} \\
\hline & Non-F-S & 0.04 & & 0.63 & \\
\hline \multirow{3}{*}{3} & & Axial Force $_{\text {Ave }}(\mathbf{k N})$ & \multirow{3}{*}{0.78} & $\operatorname{Moment}_{\text {Ave }}(\mathrm{kN} \cdot \mathrm{m})$ & \multirow{3}{*}{0.83} \\
\hline & F-S & 500.8 & & 552.7 & \\
\hline & Non-F-S & 638.26 & & 663.72 & \\
\hline \multirow{2}{*}{5} & F-S & 1173.5 & \multirow[b]{2}{*}{0.82} & 1078.2 & \multirow[b]{2}{*}{0.89} \\
\hline & Non-F-S & 1427.43 & & 1210.37 & \\
\hline \multirow{3}{*}{8} & F-S & 2250.9 & \multirow{2}{*}{0.86} & 1376.1 & \multirow{2}{*}{0.79} \\
\hline & Non-F-S & 2618.67 & & 1734.04 & \\
\hline & & Acceleration $_{\text {Ave }}\left(\mathrm{m} / \mathrm{s}^{2}\right)$ & \multirow[b]{3}{*}{0.65} & Velocity Ave $_{\text {(m/s) }}$ & \multirow{3}{*}{0.55} \\
\hline \multirow{2}{*}{3} & F-S & 17.76 & & 1.42 & \\
\hline & Non-F-S & 27.28 & & 2.56 & \\
\hline \multirow{2}{*}{5} & F-S & 18.57 & \multirow{2}{*}{0.69} & 2.06 & \multirow{2}{*}{0.75} \\
\hline & Non-F-S & 26.84 & & 2.75 & \\
\hline \multirow{2}{*}{8} & F-S & 20.48 & \multirow[b]{2}{*}{0.8} & 2.39 & \multirow{2}{*}{0.89} \\
\hline & Non-F-S & 25.46 & & 2.68 & \\
\hline
\end{tabular}

Table 6. Comparison of the mean story shear created in the stories of studied frames subjected to the simultaneous effects of the horizontal and vertical constituents of both near-fault records with fling-step and non-fling-step ground motions.

\begin{tabular}{cccc}
\hline & Near Field & Story shear $_{\text {Ave }}(\mathbf{k N})$ & F-S/Non F-S \\
\hline \multirow{3}{*}{$\mathbf{3}$} & F-S & 3856.2 & 2.28 \\
& Non-F-S & 1693.12 & \\
$\mathbf{5}$ & F-S & $11,288.9$ & 2.66 \\
& Non-F-S & 4243.55 & \multirow{2}{*}{3.11} \\
$\mathbf{8}$ & F-S & $35,543.9$ & \\
\hline
\end{tabular}

By comparing the below table results, it can be said that the response of structural excitation is subjected to the influence of the horizontal component of the near-field earthquake, given the permanent displacement of the earthquake is greater than the response of the structure subjected to the influence of the horizontal component of the far-field. This conclusion was achieved from evaluating structural excitation under the simultaneous effects of the horizontal and vertical components of both far- and near-field earthquakes (see Tables 7 and 8). 
Table 7. Comparison of the maximum means of the inter-story drift ratio, horizontal displacement, acceleration and velocity in studied frames subjected to just the horizontal component of far- and near-field earthquakes with fling-step earthquake.

\begin{tabular}{|c|c|c|c|c|c|c|c|c|c|c|c|c|c|c|c|c|c|c|c|c|c|}
\hline \multirow[t]{2}{*}{$\begin{array}{l}\text { No. } \\
\text { Story }\end{array}$} & \multicolumn{3}{|c|}{$\begin{array}{l}\text { Max Inter-Story } \\
\text { Drift Ratio }\end{array}$} & \multicolumn{3}{|c|}{$\begin{array}{l}\text { Max Displacement } \\
\text { (m) }\end{array}$} & \multicolumn{3}{|c|}{$\begin{array}{c}\text { Max Acceleration } \\
\left(\mathrm{m} / \mathrm{s}^{2}\right)\end{array}$} & \multicolumn{3}{|c|}{ Max Velocity $(\mathrm{m} / \mathrm{s})$} & \multicolumn{3}{|c|}{$\begin{array}{c}\text { Max } \\
\text { Column Axial Force } \\
(\mathbf{k N})\end{array}$} & \multicolumn{3}{|c|}{$\begin{array}{c}\text { Max } \\
\text { Story shear }(k N)\end{array}$} & \multicolumn{3}{|c|}{$\begin{array}{c}\text { Max } \\
\text { Moment Force } \\
(\mathrm{kN} \cdot \mathrm{m})\end{array}$} \\
\hline & FF & NF & atio & FF & NF & Ratio & FF & NF & Ratio & FF & NF & Ratio & FF & NF & Ratio & FF & NF & Ratio & FF & NF & Ratio \\
\hline 3 & 0 & & 3 & & & 2.80 & & & & & & & 94.43 & 580. & 1.9 & 277 & & 1. & 49 & 614.71 & 2.32 \\
\hline 5 & 0 & 0. & 6 & & & 5.8 & & & & & 5 & & 57 & 147,43 & 3.821 & 618 & & 1. & 48 & 54 & 3.02 \\
\hline 8 & 0.01 & 0.06 & 6 & .21 & 1.15 & 5.48 & 12.08 & 23.20 & 1.92 & 1.40 & 3.56 & 2.54 & 1579.56 & 299,14 & .41 .89 & 17,242 & $723,608.3$ & 331.37 & 798.33 & 2305.15 & 2.89 \\
\hline
\end{tabular}

Table 8. Comparison of the maximum mean of the inter-story drift ratio, horizontal displacement, acceleration and velocity in studied frames subjected to just the horizontal $(\mathrm{H})$ component of the far- and near-field earthquakes with the simultaneous effects of the vertical and horizontal $(\mathrm{H}+\mathrm{V})$ components with fling-step earthquakes.

\begin{tabular}{|c|c|c|c|c|c|c|c|c|c|c|c|c|c|c|c|c|c|c|c|c|c|}
\hline \multicolumn{22}{|c|}{ Near Field } \\
\hline \multirow[t]{2}{*}{$\begin{array}{l}\text { No. } \\
\text { Story }\end{array}$} & \multicolumn{3}{|c|}{$\begin{array}{c}\text { Max } \\
\text { Inter-Story Drift } \\
\text { Ratio }\end{array}$} & \multicolumn{3}{|c|}{$\begin{array}{c}\text { Max } \\
\text { Displacement (m) }\end{array}$} & \multicolumn{3}{|c|}{$\begin{array}{c}\text { Max } \\
\text { Acceleration }\left(\mathrm{m} / \mathrm{s}^{2}\right)\end{array}$} & \multicolumn{3}{|c|}{$\begin{array}{c}\text { Max } \\
\text { Velocity }(\mathrm{m} / \mathrm{s})\end{array}$} & \multicolumn{3}{|c|}{$\begin{array}{c}\text { Max } \\
\text { Column Axial Force } \\
(\mathbf{k N})\end{array}$} & \multicolumn{3}{|c|}{$\begin{array}{c}\text { Max } \\
\text { Story Shear } \\
(\mathbf{k N})\end{array}$} & \multicolumn{3}{|c|}{$\begin{array}{c}\text { Max } \\
\text { Moment Force } \\
(\mathrm{kN} \cdot \mathrm{m})\end{array}$} \\
\hline & $\mathbf{H}$ & $\mathrm{H}+\mathrm{V}$ & Ratio & $\mathbf{H}$ & $\mathrm{H}+\mathrm{V}$ & Ratio & $\mathbf{H}$ & $\mathrm{H}+\mathrm{V}$ & Ratio & $\mathbf{H}$ & $\mathrm{H}+\mathrm{V}$ & Ratio & $\mathbf{H}$ & $\mathrm{H}+\mathrm{V}$ & Ratio & $\mathbf{H}$ & $\mathrm{H}+\mathrm{V}$ & Ratio & $\mathbf{H}$ & $\mathrm{H}+\mathrm{V}$ & Ratio \\
\hline 3 & 0.03 & 0.03 & 1 & 0.28 & 0.28 & 1 & 28.41 & 28.38 & 1 & 1.56 & 1.57 & 1 & 580.12 & 582.11 & 1 & 3347. & 93940.83 & 1.18 & 614.71 & 613.56 & 1 \\
\hline 5 & 0.06 & 0.06 & 1 & 0.82 & 0.82 & 1 & 19.53 & 19.49 & 1 & 2.51 & 2.50 & 1 & 1474.39 & 1534.49 & 1.04 & 8786 & $911,727.7$ & 701.33 & 1578.54 & 1578.02 & 21 \\
\hline 8 & 0.06 & 0.06 & 1 & 1.15 & 1.15 & 1 & 23.20 & 23.34 & 1 & 3.56 & 3.56 & 1 & 2991.40 & 3109.87 & 1.04 & 23,60 & $.392,066.7$ & 761.78 & 2305.15 & 52316.94 & 41 \\
\hline \multicolumn{22}{|c|}{ Far Field } \\
\hline \multirow{2}{*}{$\begin{array}{l}\text { No. } \\
\text { Story }\end{array}$} & \multicolumn{3}{|c|}{$\begin{array}{c}\text { Max } \\
\text { Inter-Story Drift } \\
\text { Ratio }\end{array}$} & \multicolumn{3}{|c|}{$\begin{array}{c}\text { Max } \\
\text { Displacement (m) }\end{array}$} & \multicolumn{3}{|c|}{$\begin{array}{c}\text { Max } \\
\text { Acceleration }\left(\mathrm{m} / \mathrm{s}^{2}\right)\end{array}$} & \multicolumn{3}{|c|}{$\begin{array}{c}\text { Max } \\
\text { Velocity (m/s) }\end{array}$} & \multicolumn{3}{|c|}{$\begin{array}{c}\text { Max } \\
\text { Column Axial Force } \\
(\mathbf{k N})\end{array}$} & \multicolumn{3}{|c|}{$\begin{array}{c}\text { Max } \\
\text { Story Shear } \\
(\mathbf{k N})\end{array}$} & \multicolumn{3}{|c|}{$\begin{array}{c}\text { Max } \\
\text { Moment Force } \\
(\mathrm{kN} \cdot \mathrm{m})\end{array}$} \\
\hline & $\mathbf{H}$ & $\mathrm{H}+\mathrm{V}$ & Ratio & $\mathbf{H}$ & $\mathrm{H}+\mathrm{V}$ & Ratio & $\mathbf{H}$ & $\mathrm{H}+\mathrm{V}$ & Ratio & $\mathbf{H}$ & $\mathrm{H}+\mathrm{V}$ & Ratio & $\mathbf{H}$ & $\mathrm{H}+\mathrm{V}$ & Ratio & $\mathbf{H}$ & $\mathrm{H}+\mathrm{V}$ & Ratio & $\mathbf{H}$ & $\mathrm{H}+\mathrm{V}$ & Ratio \\
\hline 3 & 0.01 & 0.01 & 1 & 0.10 & 0.10 & 1 & 10.86 & 10.81 & 1 & 0.90 & 0.91 & 1.01 & 294.43 & 289.49 & 0.98 & 2777. & 93519.26 & 1.27 & 265.49 & 265.62 & 1 \\
\hline 5 & 0.01 & 0.01 & 1 & 0.14 & 0.14 & 1 & 12.65 & 12.74 & 1.01 & 1.18 & 1.18 & 1 & 712.57 & 712.57 & 1 & 6183. & 29929.37 & 1.61 & 522.48 & 522.54 & 1 \\
\hline 8 & 0.01 & 0.01 & 1 & 0.21 & 0.21 & 1 & 12.08 & 12.02 & 1 & 1.40 & 1.40 & 1 & 1579.56 & 1598.53 & 1.01 & 17,24 & .72799 .27 & 1.62 & 798.33 & 796.82 & 1 \\
\hline
\end{tabular}




\section{Conclusions}

The fling-step property due to a stationary ground displacement is generally performed through a combination of a unilateral velocity pulse and a uniform stage in the displacement time interval. The separate stage in the displacement time interval happens along the fault slip (i.e., in the direction of strike and dip for strike- and dip-slip occurrences, respectively).

According to existing studies, near-field earthquakes are characterized differently from far-field earthquakes in terms of the frequency content and amplification range. Thus, it is necessary to study the effects of such parameters on structures. With respect to near-fault fields, forward directivity and fling-step pulses may appear in the case of each component with a parallel or perpendicular position to the fault line, either separately or together in one record component. This study evaluates the seismic behaviors of three-floor, five-floor and eight-floor special steel bending frames that undergo near-field earthquakes with fling-step effects and also far-field earthquakes. This study also modeled the panel zone in order to render a more realistic behavior of the structure. Non-linear time-history analysis of the structures demonstrated that 'floor displacement', 'inter-story drift ratio', 'floor acceleration', 'axial and anchor force on the columns' and 'floor velocity' subjected to influence of the horizontal component of near-field earthquakes with a fling-step effect are greater than the corresponding values of these parameters in far-field earthquakes.

Author Contributions: S.S. and I.M. figured out the given idea. S.S. and A.K. presented the theory and conducted the computations. I.M. and J.W.H. investigated and confirmed the analytical approaches. J.W.H. and I.M. persuaded S.S. and A.K. to study both orientation and fling-step impacts and controlled the results of this research. All researchers considered the findings and provided the ultimate work.

Funding: Basic Science Research Program of the National Research Foundation of Korea (NRF) provided facilities for this research, for which the authors are grateful. Financial support of the Ministry of Science, ICT \& Future Planning (2017R1A2B2010120) is highly appreciated.

Conflicts of Interest: The authors declare no conflict of interest.

\section{References}

1. Bolt, B.A.; Abrahamson, N.A. 59 Estimation of strong seismic ground motions. Int. Geophys. 2003, 81, 983-1001. [CrossRef]

2. Ventura, C.E.; Archila, M.; Bebamzadeh, A.; Liam Finn, W.D. Large coseismic displacements and tall buildings. Struct. Des. Tall Spec. Build. 2011, 20, S85-S99. [CrossRef]

3. Grimaz, S.; Malisan, P. Near field domain effects and their consideration in the international and Italian seismic codes. Boll. Geofis. Teor. Appl. 2014, 55, 717-738. [CrossRef]

4. Avossa, A.M.; Pianese, G. Damping effects on the seismic response of base-isolated structures with LRB devices. Ing. Sismica 2017, 34, 3-29.

5. Carydis, P.; Lekkas, E. The Haiti Earthquake $\mathrm{Mw}=7.0$ of January 12 th 2010: Structural and geotechnical engineering field observations, near-field ground motion estimation and interpretation of the damage to buildings and infrastructure in the Port-au-Prince area. Ing. Sismica 2011, 28, 24-42.

6. Bhandari, M.; Bharti, S.D.; Shrimali, M.K.; Datta, T.K. Seismic Fragility Analysis of Base-Isolated Building Frames Excited by Near- and Far-Field Earthquakes. J. Perform. Constr. Facil. 2019, 33. [CrossRef]

7. Tajammolian, H.; Khoshnoudian, F.; Talaei, S.; Loghman, V. The effects of peak ground velocity of near-field ground motions on the seismic responses of base-isolated structures mounted on friction bearings. Earthq. Struct. 2014, 7, 1159-1282. [CrossRef]

8. Kalkan, E.; Kunnath, S.K. Effects of fling step and forward directivity on seismic response of buildings. Earthq. Spectra 2006, 22, 367-390. [CrossRef]

9. Mavroeidis, G.P.; Dong, G.; Papageorgiou, A.S. Near-fault ground motions, and the response of elastic and inelastic single-degree-of-freedom (SDOF) systems. Earthq. Eng. Struct. Dyn. 2004, 33, 1023-1049. [CrossRef]

10. Somerville, P.G.; Smith, N.F.; Graves, R.W.; Abrahamson, N.A. Modification of empirical strong ground motion attenuation relations to include the amplitude and duration effects of rupture directivity. Seismol. Res. Lett. 1997, 68, 199-222. [CrossRef] 
11. Baker, J.W. Identification of near-fault velocity pulses and prediction of resulting response spectra. In Proceedings of the Geotechnical Earthquake Engineering and Soil Dynamics IV, Sacramento, CA, USA, 18-22 May 2008.

12. Akkar, S.; Yazgan, U.; Gülkan, P. Drift estimates in frame buildings subjected to near-fault ground motions. J. Struct. Eng. 2005, 131, 1014-1024. [CrossRef]

13. MacRae, G.A.; Morrow, D.V.; Roeder, C.W. Near-fault ground motion effects on simple structures. J. Struct. Eng. 2001, 127, 996-1004. [CrossRef]

14. Malhotra, P.K. Response of buildings to near-field pulse-like ground motions. Earthq. Eng. Struct. Dyn. 1999, 28, 1309-1326. [CrossRef]

15. Wong, K.K.F.; Yang, R. Comparing response of SDF systems to near-fault and far-fault earthquake motions in the context of spectral regions. Earthq. Eng. Struct. Dyn. 2001, 30, 1769-1789. [CrossRef]

16. Mohseni, I.; Lashkariani, H.A.; Kang, J.; Kang, T.H.K. Dynamic response evaluation of long-span reinforced arch bridges subjected to near- and far-field ground motions. Appl. Sci. 2018, 8, 1243. [CrossRef]

17. Zhao, D.; Liu, Y.; Li, H. Self-tuning fuzzy control for seismic protection of smart base-isolated buildings subjected to pulse-type near-fault earthquakes. Appl. Sci. 2017, 7, 1185. [CrossRef]

18. Gillie, J.L.; Rodriguez-Marek, A.; McDaniel, C. Strength reduction factors for near-fault forward-directivity ground motions. Eng. Struct. 2010, 32, 273-285. [CrossRef]

19. Jalali, R.S.; Trifunac, M.D. A note on strength-reduction factors for design of structures near earthquake faults. Soil Dyn. Earthq. Eng. 2008, 28, 212-222. [CrossRef]

20. Burks, L.S.; Baker, J.W. A predictive model for fling-step in near-fault ground motions based on recordings and simulations. Soil Dyn. Earthq. Eng. 2016, 80, 119-126. [CrossRef]

21. Farid Ghahari, S.; Jahankhah, H.; Ghannad, M.A. Study on elastic response of structures to near-fault ground motions through record decomposition. Soil Dyn. Earthq. Eng. 2010, 30, 536-546. [CrossRef]

22. Shahbazi, S.; Khatibinia, M.; Mansouri, I.; Hu, J.W. Seismic evaluation of special steel moment frames undergoing near-field earthquakes with forward directivity by considering soil-structure interaction effects. Sci. Iran. 2018. [CrossRef]

23. Nastri, E.; D'Aniello, M.; Zimbru, M.; Streppone, S.; Landolfo, R.; Montuori, R.; Piluso, V. Seismic response of steel Moment Resisting Frames equipped with friction beam-to-column joints. Soil Dyn. Earthq. Eng. 2019, 119, 144-157. [CrossRef]

24. Dell'Aglio, G.; Montuori, R.; Nastri, E.; Piluso, V. Consideration of second-order effects on plastic design of steel moment resisting frames. Bull. Earthq. Eng. 2019. [CrossRef]

25. Piluso, V.; Pisapia, A.; Castaldo, P.; Nastri, E. Probabilistic Theory of Plastic Mechanism Control for Steel Moment Resisting Frames. Struct. Saf. 2019, 76, 95-107. [CrossRef]

26. Mansouri, I.; Shahbazi, S.; Hu, J.W.; Arian Moghaddam, S. Effects of pulse-like nature of forward directivity ground motions on the seismic behavior of steel moment frames. Earthq. Struct. 2019, in press.

27. Sánchez-Olivares, G.; Tomás Espín, A. Design of planar semi-rigid steel frames using genetic algorithms and Component Method. J. Constr. Steel Research. 2013, 88, 267-278. [CrossRef]

28. Macedo, L.; Silva, A.; Castro, J.M. A more rational selection of the behaviour factor for seismic design according to Eurocode 8. Eng. Struct. 2019, 188, 69-86. [CrossRef]

29. Mansouri, I.; Saffari, H. A new steel panel zone model including axial force for thin to thick column flanges. Steel Compos. Struct. 2014, 16, 417-436. [CrossRef]

30. Saffari, H.; Mansouri, I.; Bagheripour, M.H.; Dehghani, H. Elasto-plastic analysis of steel plane frames using Homotopy Perturbation Method. J. Constr. Steel Research. 2012, 70, 350-357. [CrossRef]

31. Li, S.; Xie, L.L. Progress and trend on near-field problems in civil engineering. Acta Seismol. Sin. 2007, 20, 105-114. [CrossRef]

32. Stewart, J.P.; Chiou, S.J.; Bray, J.D.; Graves, R.W.; Somerville, P.G.; Abrahamson, N.A. Ground Motion Evaluation Procedures for Performance-Based Design; PEER Report 2001/09; Pacific Earthquake Engineering Research Center, University of California Berkeley: Berkeley, CA, USA, 2001.

33. Kalkan, E.; Adalier, K.; Pamuk, A. Near source effects and engineering implications of recent earthquakes in Turkey. In Proceedings of the 5th international conference on case histories in geotechnical engineering, New York, NY, USA, 13-17 April 2004.

34. Standard2800. In Iranian Code of Practice for Seismic Resistant Design of Buildings, 4th ed.; Building and Housing Research Center: Tehran, Iran, 2014. 
35. Etemadi Mashhadi, M.R. Development of Fragility Curves for Seismic Assessment of Steel Structures with Consideration of Soil-Structure Interaction. Master's Thesis, University of Birjand, Birjand, Iran, 2015.

36. Shahbazi, S.; Mansouri, I.; Hu, J.W.; Sam Daliri, N.; Karami, A. Seismic response of steel SMFs subjected to vertical components of far- and near-field earthquakes with forward directivity effects. Adv. Civ. Eng. 2019, 2019, 2647387. [CrossRef]

37. Shahbazi, S.; Mansouri, I.; Hu, J.W.; Karami, A. Effect of soil classification on seismic behavior of SMFs considering soil-structure interaction and near-field earthquakes. Shock Vib. 2018, 2018, 4193469. [CrossRef]

38. Lignos, D.G.; Krawinkler, H. Sidesway Collapse of Deteriorating Structural Systems under Seismic Excitations; Rep. No. 172; John A. Blume Earthquake Engineering Center, Stanford University: Stanford, CA, USA, 2009.

39. Gupta, A.; Krawinkler, H. Seismic Demands for Performance Evaluation of Steel Moment Resisting Frame Structures; Rep. No. 132; John A. Blume Earthquake Engineering Center, Stanford University: Stanford, CA, USA, 1999.

40. OpenSees. Open System for Earthquake Engineering Simulation. Available online: http://opensees.berkeley. edu:PEER (accessed on 16 May 2019).

41. Ibarra, L.F.; Krawinkler, H. Global Collapse of Frame Structures under Seismic Excitations; Rep. No. 152; John A. Blume Earthquake Engineering Center, Stanford University: Stanford, CA, USA, 2005.

(C) 2019 by the authors. Licensee MDPI, Basel, Switzerland. This article is an open access article distributed under the terms and conditions of the Creative Commons Attribution (CC BY) license (http://creativecommons.org/licenses/by/4.0/). 